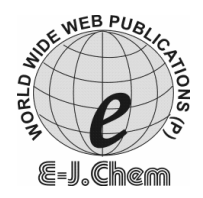

http://www.e-journals.net
ISSN: 0973-4945; CODEN ECJHAO

E-Journal of Chemistry 2010, 7(3), 908-914

\title{
An Investigation of the Quality of Underground Water at Eloor in Ernakulum District of Kerala, India
}

\author{
A.G. UMADEVI, M.GEORGE* ${ }^{*}$ P. DHARMALINGAM, \\ JOSE.P.ABRAHAM ${ }^{\S}$, M.RAJAGOPALAN ${ }^{\S}$, DHANYA BALAKRISHNAN ${ }^{\S}$, \\ P.P. HARIDASAN ${ }^{\#}$ and P.M. B.PILLAI ${ }^{\#}$ \\ PG and Research Department of Chemistry, \\ Urummu Dhanalakshmi College, Tiruchirappali 620019, India. \\ ${ }^{\S}$ Centre for Environmental \& Radiological Sciences, \\ Department of Physics, The Cochin College, Kochi-2, Kerala, India. \\ *Department of Chemistry and Research Centre, \\ Sacred Heart College, The vara, Kochi-13, Kerala, India. \\ ${ }^{\#}$ Environmental Assessment Division, Bhabha Atomic Research Centre, \\ Health Physics Unit, IREL, Udyogmandal, Kerala-683 501 India. \\ georgem_mathai@yahoo.co.in
}

Received 28 October 2009; Accepted 20 December 2009

\begin{abstract}
The physical and chemical properties of groundwater in Eloor, an industrial region, have been investigated to evaluate the extent of pollution. The study area was divided into four zones and a total of 40 water samples from different locations were collected, analyzed and correlation analysis has been carried out among the measured parameters. A comparison of the observed parameters with the limits prescribed by BIS revealed that in some area $\mathrm{pH}$ values are lower than the prescribed limit. The concentration of the major cations and anions were found to be significant. Magnesium and chloride exceed the desirable limit in some areas but less than the upper limit prescribed by BIS. Significant linear relationship was observed between $\mathrm{pH}$, electrical conductivity, alkalinity, hardness, $\mathrm{Ca}^{2+}, \mathrm{Mg}^{2+}$ and chloride. The importance of these parameters in predicting the quality characteristics of groundwater is discussed.
\end{abstract}

Keywords: Physicochemical parameters, BIS limits, Groundwater, Eloor.

\section{Introduction}

The potential and quality of groundwater, is an economic resource and essential component of our life, is getting deteriorated in major cities and urban centers due to pollution caused by population explosion, urbanization and industrialization ${ }^{1,2}$. Industrialization causes large 
volume of effluent to discharge that may affect the groundwater quality since the effluent from discharges or run-off from solid waste disposal sites generally moves vertically downdards ${ }^{3}$. In India, groundwater is polluted to varying degrees at different industrial regions as evidenced by recent reports ${ }^{4}$. The extent of pollution depends on the rainfall pattern, depth of water table distance from the source of contamination and soil properties like permeability, composition of its recharge components as well as geology and hydrology of the area ${ }^{5}$.

Pollutants may remain concealed for many years, becoming dispersed over wide areas of groundwater aquifer and rendering groundwater supplies unsuitable for consumption and other uses ${ }^{6}$. In industrial regions, physicochemical parameters of water such as hardness, COD, BOD, chloride, nitrate, phenols, cyanides, calcium and heavy metals increases with time. The total potential of groundwater in India is $4.2 \times 10^{10} \mathrm{~m}^{3}$, a quarter of it is being used for irrigation, industrial and domestic purposes ${ }^{7}$.

Eloor is the industrial belt in the Ernakulam district of Kerala, which covers $11.2 \mathrm{sq} . \mathrm{km}$, within the latitude of $10{ }^{0} 5^{\prime}$ North and $76{ }^{\circ} 16^{\prime}$ East longitude and is at an elevation of $4.3 \mathrm{~m}$ above MSL (Mean Sea Level). There are nearly 8,245 houses in Eloor and a population of 30,092 as per census 2001. The major industries in Eloor include phosphate fertilizer plant, monazite industry, caustic soda unit, pesticide plant, aluminum and zinc smelter and factory for synthetic rutile. In addition, there are small industries manufacturing petrochemical products, pesticides, insecticides, rare earth elements, rubber products, zinc/chromium compounds and leather products. The industrial region in Kerala, Eloor, warrants an assessment of the quality of groundwater to assess the suitability for drinking and other uses as well as to indicate the levels of chemical pollutants to which the local population are exposed. The present paper gives the result of a systematic study carried out in the area.

\section{Experimental}

The study area in Eloor region was divided into four zones namely East, West, North and South focuzing the major industrial spot as the central point and samples were collected from different points in each zone, during January-February 2008. A total of 40 samples (East -12, West -8, North -10 and South -10) were collected from the open wells in pre-cleaned dry polypropylene bottles. The physicochemical parameters such as $\mathrm{pH}$, electrical conductivity, alkalinity, total dissolved solids, chloride, total hardness, calcium, magnesium, sodium, potassium, nitrate, sulphate were estimated by standard methods ${ }^{8}$. The models of the instruments used for different parameters are shown in Table 1. Analytical grade chemicals were used to prepare reagents and calibration standards. The measured parameters were compared with the guidelines suggested by BIS (Bureau of Indian standards) for drinking water'.

Table 1. Analytical methods for quality parameters of groundwater.

\begin{tabular}{ll}
\hline \multicolumn{1}{c}{ Parameter } & \multicolumn{1}{c}{ Method } \\
\hline $\mathrm{pH}$ & Digital $\mathrm{pH}$ meter(EUTECH Model pH: 510) \\
Electrical Conductivity(EC) & Digital Conductivity meter (EUTECH Model con \\
Alkalinity & $: 510)$ \\
Total dissolved solids & Titrimetry (using HCl) \\
Chloride & Indirect method. TDS=0.64×EC $\mu \mathrm{s} / \mathrm{cm}{ }^{10}$ \\
Total hardness, Calcium, Magnesium & Mohr's Argentometric method \\
Sodium, Potassium & EDTA titrimetric method \\
Nitrate & Flame photometer (SYSTRONICS Model: 125). \\
Sulphate & UV Visible Spectrophotometer, (Hitachi 3210). \\
\hline
\end{tabular}




\section{Results and Discussion}

The properties of the water samples, collected from the four zones of Eloor, were analyzed and the parameters obtained are presented in the Table 2 and 3. The data indicate that the water quality parameters vary considerably from location to location.

Table 2. The physicochemical parameters of groundwater samples of Eloor (Eastern and Western) in ppm.

\begin{tabular}{lcccccc}
\hline \multirow{2}{*}{ Parameter } & \multicolumn{3}{c}{ East } & \multicolumn{3}{c}{ West } \\
\cline { 2 - 6 } & Minimum & Maximum & Mean & Minimum & Maximum & Mean \\
\hline $\mathrm{pH}$ & 3.9 & 7.6 & 6.2 & 6.4 & 6.6 & 6.5 \\
$\mathrm{EC}(\mu \mathrm{S} / \mathrm{cm})$ & 95.0 & 399.0 & 230.0 & 380.0 & 910.0 & 727.0 \\
$\mathrm{TDS}$ & 60.8 & 255.4 & 147.4 & 243.2 & 582.4 & 465.1 \\
Alkalinity & 25.0 & 175.0 & 70.0 & 30.0 & 120.0 & 72.0 \\
Hardness & 30.0 & 210.0 & 78.9 & 175.0 & 360.0 & 258.0 \\
Sodium & 0.3 & 4.6 & 1.9 & 2.7 & 23.6 & 13.4 \\
Potassium & 1.0 & 7.7 & 3.9 & 3.8 & 10.6 & 8.2 \\
Calcium & 10.0 & 66.0 & 24.4 & 24.0 & 74.0 & 44.7 \\
Magnesium & 1.2 & 10.9 & 4.9 & 28.0 & 42.6 & 35.6 \\
Chloride & 25.0 & 150 & 82.8 & 75.0 & 375.0 & 236.7 \\
Sulphate & 1.2 & 65.0 & 19.9 & 12.6 & 40.0 & 22.3 \\
Nitrate & 2.4 & 8.9 & 4.7 & 2.0 & 7.1 & 5.2 \\
\hline
\end{tabular}

Table 3. The physicochemical parameters of groundwater samples of Eloor (Nothern and Southern region) in ppm.

\begin{tabular}{lcccccc}
\hline \multirow{2}{*}{ Parameter } & \multicolumn{3}{c}{ Eloor North } & \multicolumn{3}{c}{ Eloor South } \\
\cline { 2 - 7 } & Minimum & Maximum & Mean & Minimum & Maximum & Mean \\
\hline $\mathrm{pH}$ & 6.2 & 6.7 & 6.4 & 5.2 & 7.7 & 6.5 \\
$\mathrm{EC}(\mu \mathrm{S} / \mathrm{cm})$ & 254.0 & 1072.0 & 446.0 & 152.0 & 714.0 & 319.0 \\
$\mathrm{TDS}$ & 162.6 & 870.0 & 377.6 & 97.3 & 457.0 & 205.4 \\
Alkalinity & 25.0 & 40.0 & 32.0 & 20.0 & 175.0 & 61.0 \\
Hardness & 65.0 & 250.0 & 125.0 & 60.0 & 240.0 & 96.0 \\
Sodium & 1.6 & 12.2 & 3.8 & 0.4 & 4.4 & 1.4 \\
Potassium & 6.2 & 14.5 & 8.6 & 2.0 & 167.0 & 18.9 \\
Calcium & 1.8 & 70.0 & 26.8 & 20.0 & 50.0 & 27.6 \\
Magnesium & 2.4 & 20.7 & 11.9 & 1.2 & 38.9 & 6.8 \\
Chloride & 100.0 & 714.0 & 234.8 & 25.0 & 125.0 & 46.0 \\
Sulphate & 15.0 & 34.0 & 25.8 & 2.5 & 48.2 & 18.6 \\
Nitrate & 3.5 & 14.6 & 8.4 & 2.9 & 23.3 & 9.0 \\
\hline
\end{tabular}

The $\mathrm{pH}$ of water samples ranged from 3.9 to 7.7 with low values for samples from east and south region. The low $\mathrm{pH}$ may cause desorption of metal cations due to competition by $\mathrm{H}^{+}$ions and it alters the taste of water ${ }^{11},{ }^{12}$. About $40 \%$ of the water samples have $\mathrm{pH}$ lower than the BIS prescribed limit of 6.5-8.5.

The conductivity of water is directly related to the concentration of ions and their mobility. Studies revealed that EC value is the indication of dissolved ionizable solids ${ }^{13}$. Electrical Conductivity (EC) varies between 95 to $1072 \mu \mathrm{mho} / \mathrm{cm}$ and significantly high in few samples from the western and northern region indicating the presence of ionic contaminants (Figure 1). 
Total Dissolved Solids (TDS) ranges from 29.8 to $739.2 \mathrm{mg} / \mathrm{L}$ (Figure 1), showing high values for the samples from west zone which may be attributed to the leaching of industrial effluents or backwater intrusion. About $23 \%$ of samples exceed the desirable limit of $300 \mathrm{mg} / \mathrm{L}$ but lies within the maximum permissible limit prescribed by BIS.

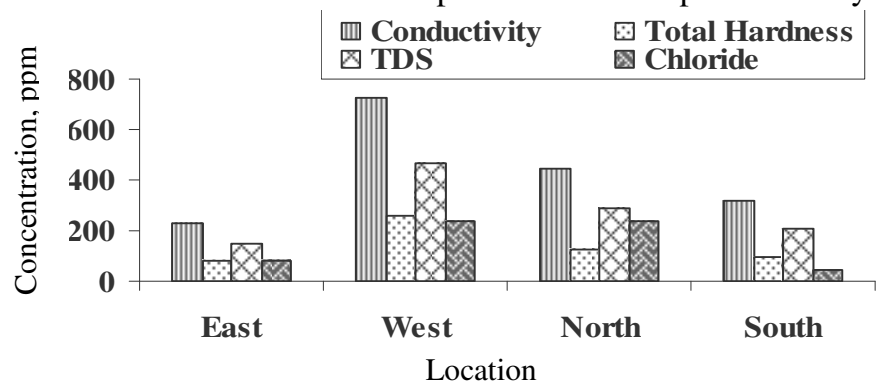

Figure 1. Variation of TDS, EC, $\mathrm{TH}$ and $\mathrm{Cl}^{-}$in the groundwater samples of Eloor region.

Alkalinity leads to corrosion and influences the chemical and biochemical reactions. Alkalinity was observed in the range 25 to $175 \mathrm{mg} / \mathrm{L}$, within the permissible limit of $200 \mathrm{mg} / \mathrm{L}$. Low value of alkalinity in eastern region is indicative of low $\mathrm{pH}$ value, Table 2. Total Hardness (TH), indicates calcium and magnesium content, ranges from $30 \mathrm{mg} / \mathrm{L}$ to $360 \mathrm{mg} / \mathrm{L}$ (mean $=138$ $\mathrm{mg} / \mathrm{L}$ ), showing high values for the samples from west region. Hardness of water is not a health hazard but its value should remain below permissible limit to restore the taste of water ${ }^{14}$. Based on the TH observed, the samples fall into four categories: (i) $17 \%$ is very hard water having $\mathrm{TH}$ more than $180 \mathrm{mg} / \mathrm{L}$, (ii) $10 \%$ is hard water (TH from $120-180 \mathrm{mg} / \mathrm{L}$ ), (iii) $62 \%$ belong to medium hard water (TH from $60-120 \mathrm{mg} / \mathrm{L}$ ) and (iv) $13 \%$ is soft water (TH from 0-60 mg/L).

The concentration of calcium ranges from 1.8 to $74 \mathrm{mg} / \mathrm{L}$ with the maximum in the west region (Figure 2). The high concentration of $\mathrm{Ca}$ may be due to the discharge of industrial waste and passage through deposits of limestone, dolomite, and gypsum ${ }^{15}$. Water containing high calcium is not suitable for washing, bathing and in boilers and linked to the formation of concretion in the body and may cause gastro intestinal diseases and stone formations.

Magnesium is a beneficial metal but toxic at high concentrations, causes hardness and exerts a cathartic and diuretic action ${ }^{15}$. The concentration of magnesium ranges from $1.2-42.6 \mathrm{mg} / \mathrm{L}$ with slight variation in different locations and in some of the samples (west) it exceeds the desirable limit of $30 \mathrm{mg} / \mathrm{L}$ prescribed by BIS but lies within the maximum permissible limit of $75 \mathrm{mg} / \mathrm{L}$.

The concentration of potassium ranges from $1 \mathrm{mg} / \mathrm{L}$ to $167 \mathrm{mg} / \mathrm{L}$, with maximum value in the south region and minimum in the east region (Figure 2). The high concentration of potassium may be due to the influence of the fertilizer plant located in the study area. The concentration of sodium ranges from 0.3 to $23.6 \mathrm{mg} / \mathrm{L}$, with maximum value in the western region probably due to saline water intrusion. Discharge of domestic and industrial effluent on to the ground is another source of sodium in water.

The chloride content ranges from 25 to $714 \mathrm{mg} / \mathrm{L}$ (mean-370 mg/L), with high concentration for samples in the western region indicating industrial sewage pollution as well as ingress of saline water from backwaters and causes salt taste. A few samples in the northern region exceeds the desirable limit of $250 \mathrm{mg} / \mathrm{L}$ prescribed by BIS, but lies within the maximum permissible limit of $1000 \mathrm{mg} / \mathrm{L}$ (Table 3).

The concentration of sulphate ranged between 1.2 and $65 \mathrm{mg} / \mathrm{L}$ (mean-30 mg/L) (Figure 2), showing maximum in the north region and minimum in the south. High concentration of sulphate along with sodium and magnesium in drinking water can lead to gastrointestinal irritation and respiratory illness. 


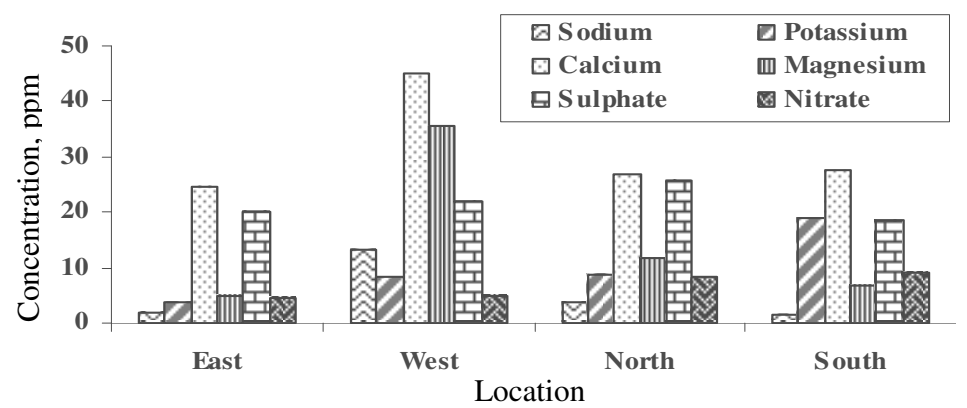

Figure 2. Variation of $\mathrm{Na}^{+}, \mathrm{K}^{+}, \mathrm{Ca}^{2+}, \mathrm{Mg}^{2+}, \mathrm{SO}_{4}{ }^{2-}$ and $\mathrm{NO}_{3}{ }^{-}$ion in the groundwater samples.

The concentration of nitrate ranges between 2.0 and $23.3 \mathrm{mg} / \mathrm{L}$ (mean-19 mg/L) indicates there may be possibility for leaching of nitrate to nearby groundwater sources. The concentration of nitrate in drinking water causes adverse effects since it is a strong oxidizing agent and $\mathrm{NO}_{2}$ can react with secondary amines present in human body, it may form nitrosamines. Biological oxidation of nitrogenous substances and bacterial action from sewage is the main source of nitrate ${ }^{16}$.

\section{Correlation}

Correlation studies are very important in water quality assessment because it determines the effect of one element on the other. The larger the numerical value of the correlation coefficient, the greater is the extend to which correlation holds between the two variables. Significant positive correlation is observed between EC, TH and chloride, Figure 3 indicating that the EC and hardness are caused by dissolved ionic solids. Magnesium and calcium showed a significant positive correlation with $\mathrm{TH}$ indicating that the hardness of water may be contributed by calcium and magnesium (Figure 4). Potassium did not show significant correlation with other major ions. Sodium showed significant positive correlations with chloride ion $\left(\mathrm{R}^{2}=0.52\right)$ may be attributed to the same source of these ions (Figure 5).

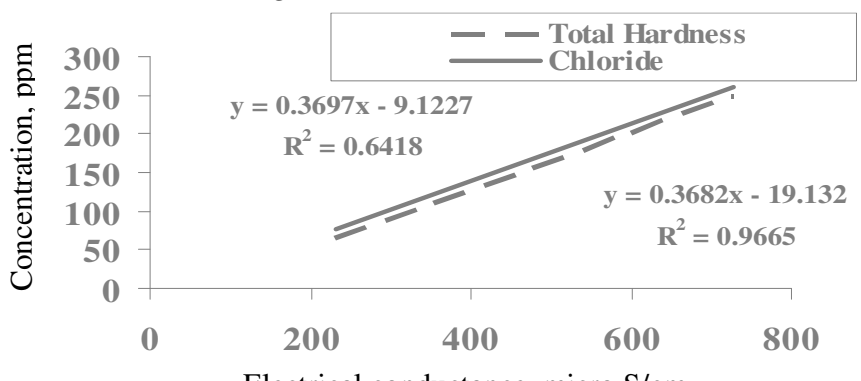

Electrical conductance, micro $\mathrm{S} / \mathrm{cm}$

Figure 3. Correlation of EC with $\mathrm{TH}$ and Chloride.

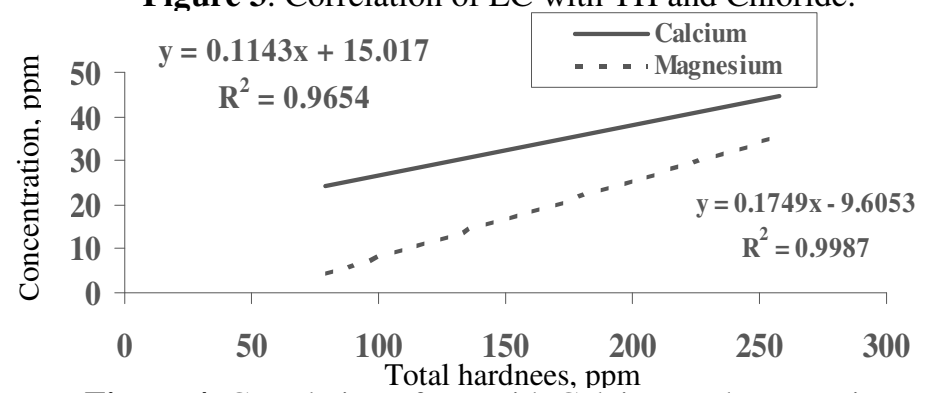

Figure 4. Correlation of TH with Calcium and Magnesium. 


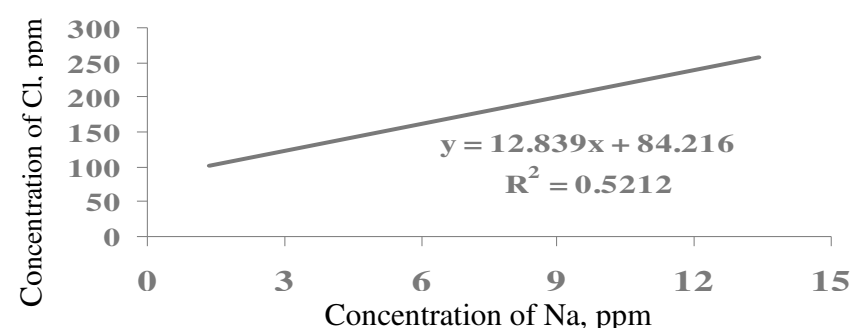

\section{Conclusion}

Figure 5. Correlation between sodium and chloride

The important physicochemical parameters of groundwater samples collected from 40 locations in Eloor were estimated. It was observed that the $\mathrm{pH}$ is low in the eastern region but TDS, total hardness and chloride are high for the water samples from west zone compared to other zones. The groundwater samples from western zone showed higher values compared to other locations in the case of water quality parameters analysed .Only very few samples showed values above the desirable limits whereas the concentration of parameters in most of the samples are below the limit prescribed by BIS. The parameters EC, TH, sodium, magnesium, calcium,chloride have good correlation in the water sample analyzed and equations obtained from the correlation analysis are very useful in the rapid analysis of groundwater quality of Eloor. It is intended that this study can be extended to monitor the concentration of other parameter including heavy metals to have an overall picture of water quality of Eloor.

\section{Acknowledgement}

The authors are grateful to Sri.H.S.Kushwaha, Director, Health Safety and Environment Group, BARC, Mumbai, Sri V.D. Puranik, Head, Environmental Assessment Division., BARC and Dr. R.M.Tripathi, Head, Radiation Protection Section (Nuclear Fuels) Environmental Assessment Division., BARC for providing the guidance and support to carry out this work. This work has been done as a part of the research project granted by Board of Research in Nuclear Sciences (BRNS), Department of Atomic Energy, Government of India. (Sanction No. 2007/36/57-BRNS/2416 dated 18-1-08)

\section{References}

1. Ramakrishnaiah C R, Sadashivaia C and Ranganna G, E Journal of Chemistry, 2009, 6(2), 523.

2. Nageswara Rao K, Swarna Latha P and Ramesh Kumar P V, Indian J Environ Prot., 2007, 27(11), 996.

3. Shrivastava V S and Vaishnav S N, Indian J Environ Prot., 2002, 22(5), 559-563.

4. Geetha A, Palanisamy P, Sivakumar P, Ganesh Kumar P and Sujatha M, E Journal of Chemistry, 2008, 5(4), 696.

5. De A K, Environmental Chemistry $3{ }^{\text {rd }}$ Edn. Wiley Eastern Ltd., New Delhi, 1995.

6. Jain C K, Kumar C P and Sharma M K, Indian J Environ Ecoplan., 2003, 7(2), 409.

7. Gupta Sunit and Mukta Gupta, Water and Basic Environmental Technology, Resources Management and Pollution Control, 1997, 1-55.

8. APHA, Standard methods for the examination of water and waste water. $21^{\text {st }}$ Edn. American Public Health Association, Washinton, D.C, 2000.

9. BIS, Indian standards specifications for drinking water. IS: 10500, Bureau of Indian Standards, New Delhi, 2003. 
10. Raghunath H M, Groundwater, New Age International Pvt Ltd., New Delhi. 2003, 344.

11. Boominanthan R and Mazhar Nazeeb Khan S M, Environ Ecol., 1994, 12(4), 850-853.

12. Trivedi R K and Geol P K, Environmental Publications, Karad, 1986.

13. Gupta S, Bhatnagar M and Jain R, Asian J Chem., 2003, 15, 71-78.

14. WHO, Guidelines for drinking water Quality: Vol. 1, Recommendations, WHO, Geneva, 1984.

15. APHA, Standard methods for the examination of water and waste water $16^{\text {th }}$ Ed., American public Health Association, Networks, 1985.

16. Suresh C, B D Tripathi and Mishra B P, Comp Physio Eco., 1992, 17(3), 92-96. 


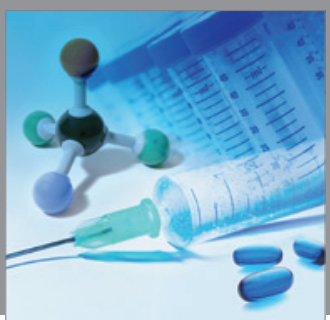

International Journal of

Medicinal Chemistry

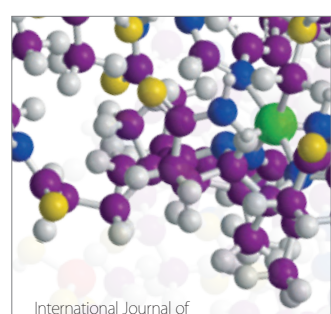

Carbohydrate Chemistry

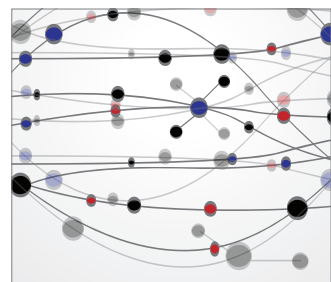

The Scientific World Journal
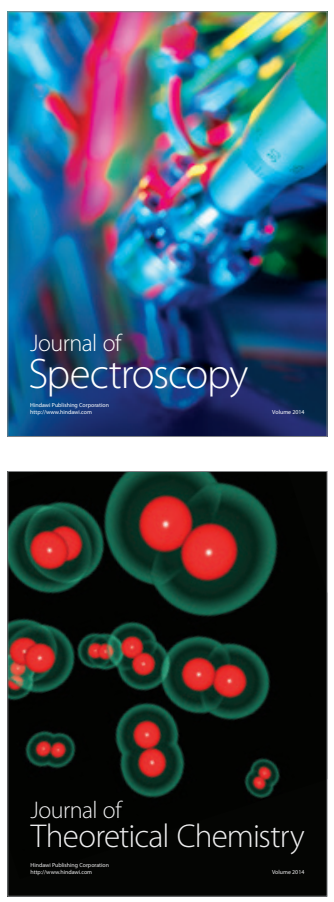
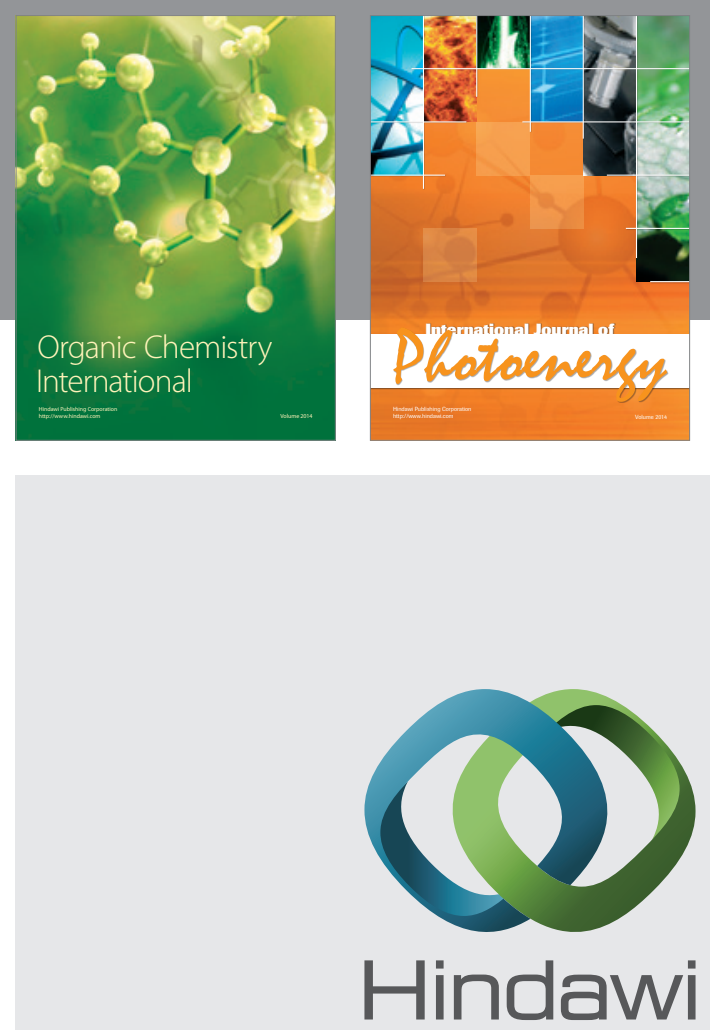

Submit your manuscripts at

http://www.hindawi.com
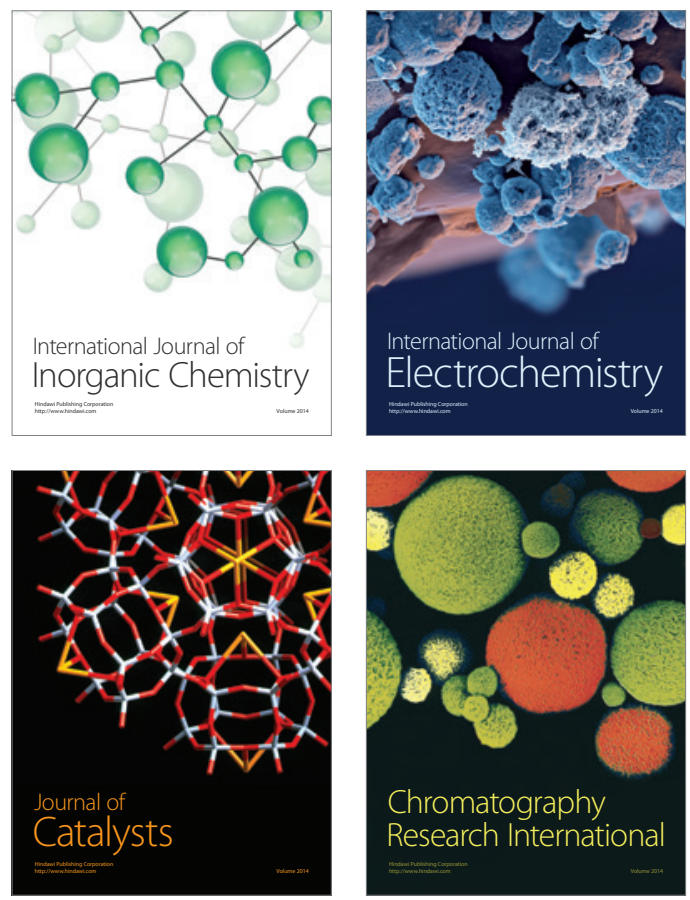
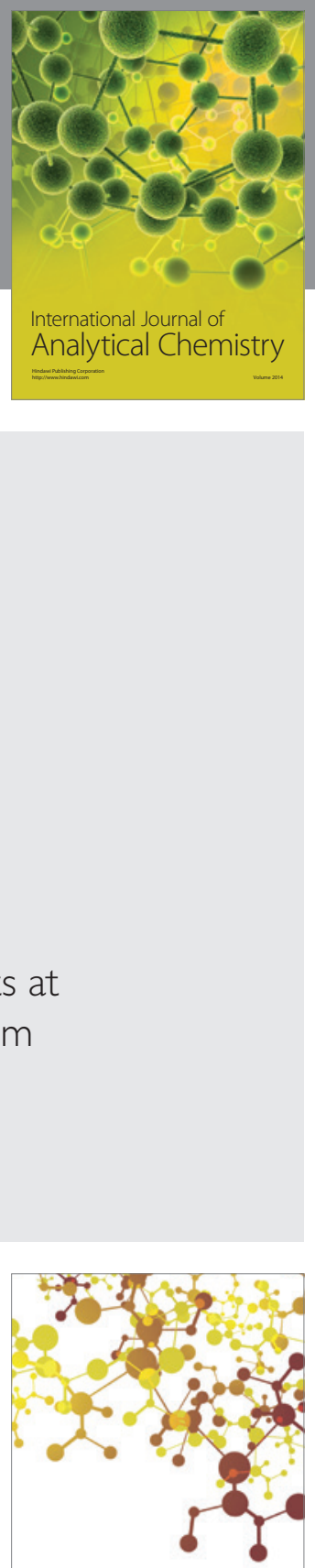

Journal of

Applied Chemistry
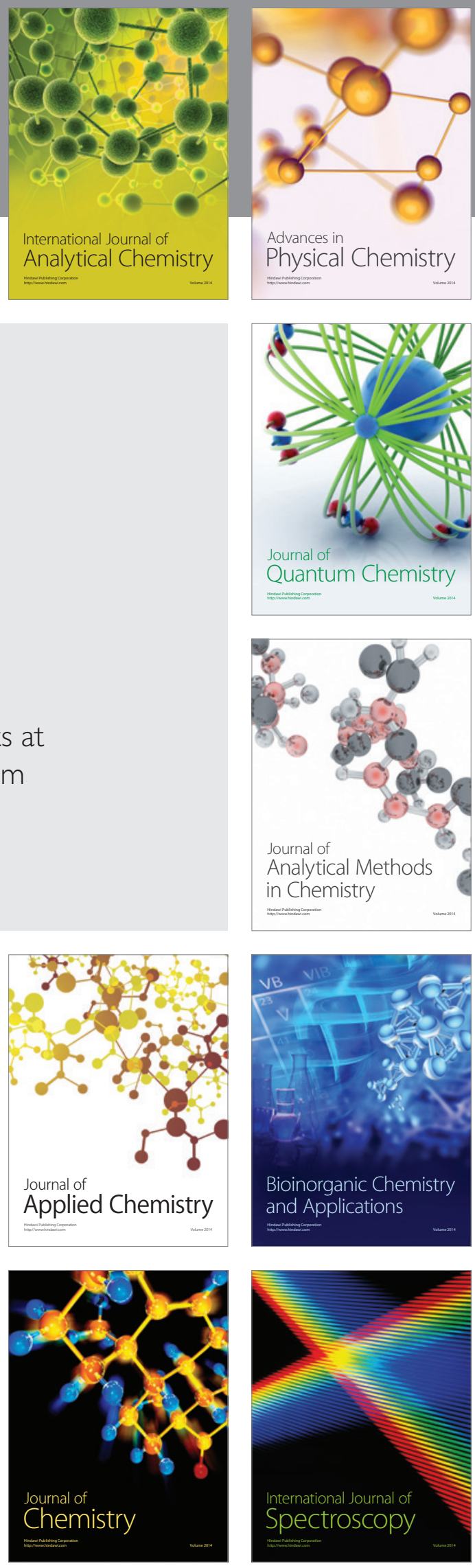